\title{
PENYEDIAAN SARANA AIR BERSIH KELOMPOK TANI MAWAR MAJU III DESA GUNUNGSARI, KECAMATAN BUMIAJI, KOTA BATU
}

\author{
Ismi Choirotin ${ }^{1)}$, Cynthia Permata Dewi ${ }^{2)}$, Nur Robbi ${ }^{3)}$ \\ 1,2,3) Fakultas Teknik Universitas Islam Malang. \\ E-mail: ismi.choirotin@unisma.ac.id ${ }^{1)}$
}

\begin{abstract}
Abstrak
Kelompok Tani Mawar Maju III adalah salah satu kelompok tani di Desa Gunungsari yang komoditi utamanya adalah bunga mawar potong. Kelompok tani ini memiliki permasalahan utama yaitu harus membeli air bersih dari desa lain untuk kebutuhan rumah tangga, dan harus mengeluarkan tenaga lebih untuk irigasi secara manual, padahal dibagian bawah lahan pertanian kelompok tani ini terdapat sumber mata air bersih dengan debit yang besar dan mengalir sepanjang tahun. Permasalahan lain yang dihadapi adalah adanya limbah berupa daun mawar yang tidak dikelola dan dimanfaatkan dengan baik, sehingga menimbulkan dampak pada lingkungan. Dari segi kelembagaan, masalah yang dihadapi oleh kelompok tani ini adalah kurangnya pengetahuan tentang teknologi dalam bidang pertanian dan rendahnya regenerasi dalam pengelolaan usaha pertanian mawar potong. Program Kemitraan Masyarakat ini akan memberi solusi berupa pemanfaatan pompa hidram dan pipanisasi untuk pengadaan air bersih dan irigasi, serta pengadaan sarana dan pelatihan pengomposan untuk mengolah limbah daun mawar. Dalam kelembagaan dan regenerasi, akan dilakukan penyuluhan dan kaderisasi terhadap generasi lapis sehingga keberlangsungan pertanian mawar potong ini akan berkelanjutan. Dengan adanya program ini, diharapkan akan memberi solusi bagi mitra berupa peningkatan perekonomian, peningkatan produktivitas lahan pertanian, peningkatan kualitas dan SDM berupa kemampuan pengolahan limbah pertanian, kemampuan dalam pemanfaatan dan perawatan penggunaan teknologi berupa pompa hidram , serta peningkatan kuantitas SDM produktif pada Kelompok Tani Mawar Maju III. Hasil fisik dari pelaksanaan Program Kemitraan Masyarakat ini adalah bangunan bendung air, pemasangan pompa hidram, pipanisasi dan bangunan tandon air sebagai bak tampung serta sarana pengomposan limbah daun mawar. Kualitas SDM juga mengalami peningkatan berupa pengetahuan dan skill anggota kelompok tani tentang teknologi pompa hidram dan perawatannya, serta proses pembuatan pupuk kompos.
\end{abstract}

Kata Kunci : Pompa Hidram, Pipanisasi, Limbah Mawar

\section{PENDAHULUAN}

Kelompok tani mawar maju III adalah salah satu kelompok tani di Desa Gunungsari. Desa Gunungsari adalah sebuah desa yang terletak di Kecamatan Bumiaji, Kota Batu, Provinsi Jawa Timur. Dibagian bawah lahan pertanian Kelompok Tani Mawar Maju III ini, terdapat sumber mata air bersih dengan debit cukup besar. Namun, pada prakteknya memanfaatan sumber air bersih ini mengalami kendala karena posisinya yang berada dibagian bawah permukiman warga dan lahan pertanian. Pompa hidram eksisting yang ada sudah tidak berfungsi dengan baik lagi, sehingga warga harus mengangkut air melewati medan dengan kemiringan tinggi untuk memenuhi kebutuhan irigasi peranian. Untuk memenuhi kebutuhan air bersih rumah tangga warga harus membeli air dari desa lain yang posisinya lebih tinggi, padahal mereka memiliki sumber mata air bersih dengan debit yang besar.

Permasalahan lain adalah adanya limbah daun mawar ini tidak terkelola dengan baik, karena pihak pemerintah kota hanya mengangkut limbah hasil rumah tangga untuk di olah di Tempat Pembuangan Akhir (TPA). Saat ini limbah daun mawar ini hanya ditumpuk di depan rumah warga, ditumpuk di lahan pertanian masing-masing. Limbah daun mawar ini akhirnya membusuk dan menimbulkan bau yang tidak sedap yang mengganggu masyarakat.

Dilihat dari sisi kelembagaan, untuk kelompok tani ini sudah cukup berjalan dengan baik. Namun, tidak adanya kelompok lapis sebagai agen perubahan yang memberikan inovasi dan meningkatkan pengetahuan pada para anggota kelompok tani sehingga kelompok tani ini menjadi kurang bisa berkembang.

\section{METODE KEGIATAN}

Untuk menyelesaikan permasalahan yang terjadi pada mitra, ada beberapa tahapan yang dilakukan pada program kemitraan masyarakat, yaitu:

1. koordinasi dengan pihak kelompok tani tentang pelaksanaan dari kegiatan kemitraan masyarakat ini. 
2. Tahap perencanaan yang meliputi perhitungan kapasitas pompa hidram dan menentukan spesifikasi pompa. Perencanaan jalur pipanisasi, perencanaan pembangunan tandon dan bak tampung.

3. Sosialisasi program kemitraan masyarakat kepadaa anggota kelompok tani.

4. Pelaksanaan pembuatan bak tampung (di sumber mata air) dan tandon air yang diposisikan di lebih tinggi dari pemukiman penduduk dan lahan pertanian.

5. Pemasangan pompa hidram dan pipanisasi dari sumber menuju pompa hidram, dan dari pompa hidram menuju tandon air.

6. Pelatihan pengoperasian dan perawatan pompa hidram serta cara pembuatan kompos dari limbah mawar

7. Evaluasi keberhasilan program.

\section{HASIL DAN PEMBAHASAN}

\section{Koordinasi dengan perwakilan mitra}

Koordinasi dengan pihak perwakilan mitra dilakukan beberapa kali untuk mendiskusikan pelaksanaan program kemitraan masyarakat. Koordinasi ini diperlukan untuk mensingkronkan perencanaan dari program, dengan kondisi aktual di lapangan. Dengan adanya kegiatan koordinasi ini, maka proses berjalannya program akan lebih mudah dan terorganisir.

Tahap perencanaan dan Pengukuran

Pada tahap ini, dilakukan perencanaan dengan mengukur debit sumber air dan perbedaan ketinggian dari masing-masing sarana yang akan dibangun. Pengukuran debit sumber air dilakukan dengan cara manual, yaitu dengan menampung air pada wadah dalam waktu tertentu. Volume dari air tersebut dihitung dan dibagi dengan waktu maka akan akan didapatkan debit sumber air tersebut. Pengukuran debit air ini dilakukan 10 kali dan dirata-rata untuk mendapatkan data pendekatan kondisi aktual.

Pengukuran perbedaan ketinggian antara pompa, bak tampung dan tandon air dilakukan dengan menggunakan bantuan alat theodolite. Pengukuran ini dilakukan untuk menghitung ukuran pompa hidram yang akan digunakan, diameter dan panjang pia yang akan digunakan. Proses pengukuran lapangan ini seperti yang ditunjukkan pada gambar 1 .

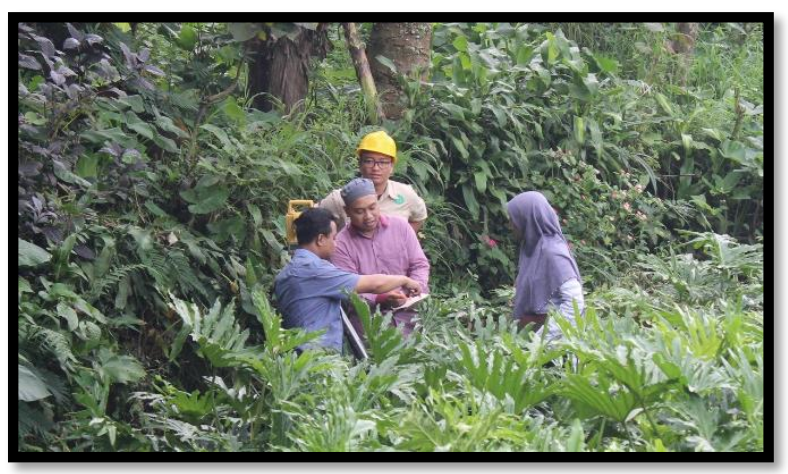

Gambar 1. Pengukuran lapangan

\section{Sosialisasi program}

Proses sosialisasi program dilakukan untuk memberi gambaran pada masyarakat tentang kegiatan yang akan dilakukkan dalam rogram kemitraan masyarakat ini. Dalam program sosialisasi ini, juga diberikan penjelasan tentang pemanfaata teknologi berupa pompa hidram yang beriperasi tanpa menggunakan listrik. Sosialisasi kedua dilakukan untuk mensosialisasikan program yang kedua yaitu cara pemanfaatan limbah daun mawar menjadi pupuk kompos.

\section{Pembuatan tandon air dan bak tampung}

Tandon air dibangun di ketinggian $30 \mathrm{~m}$ dari pemasangan pompa dan posisinya lebih tinggi dari permukiman warga serta lahan pertanian, dengan harapan air hanya memerlukan gaya grafitasi untuk memenuhi kebutuhan warga dan irigasi. Tandon air ini dibuat dengan ukuran 3,5 x 2,5 × $2 \mathrm{~m}$, dengan kapasitas tampung 17500 liter. Bangunan tandon air seperti yang diperlihatkan pada gambar 2 .

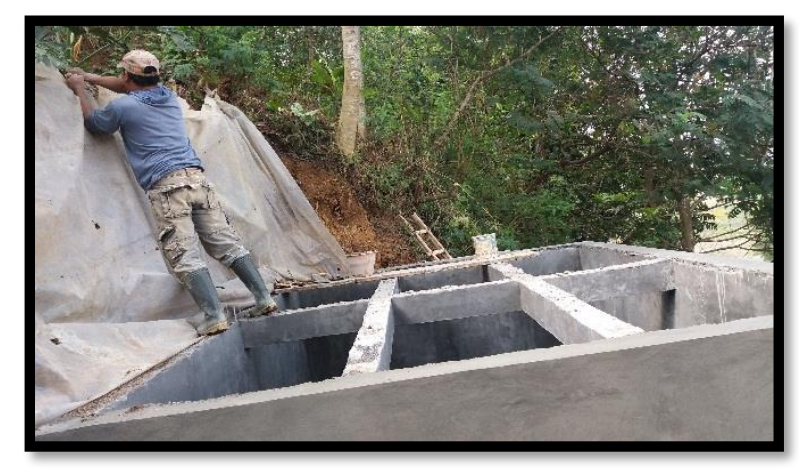

Gambar 2. Tandon air

Bak tampung dibuat untuk menampung air dari sumber mata air sebelum dialirkan menuju pompa hidram. Bangunan bak tampung ini dibuat dengan ukuran $1 \times 1 \times 1,5 \mathrm{~m}$. Gambar dari bak tampung seperti yang dierlihat kan gambar 3 . 


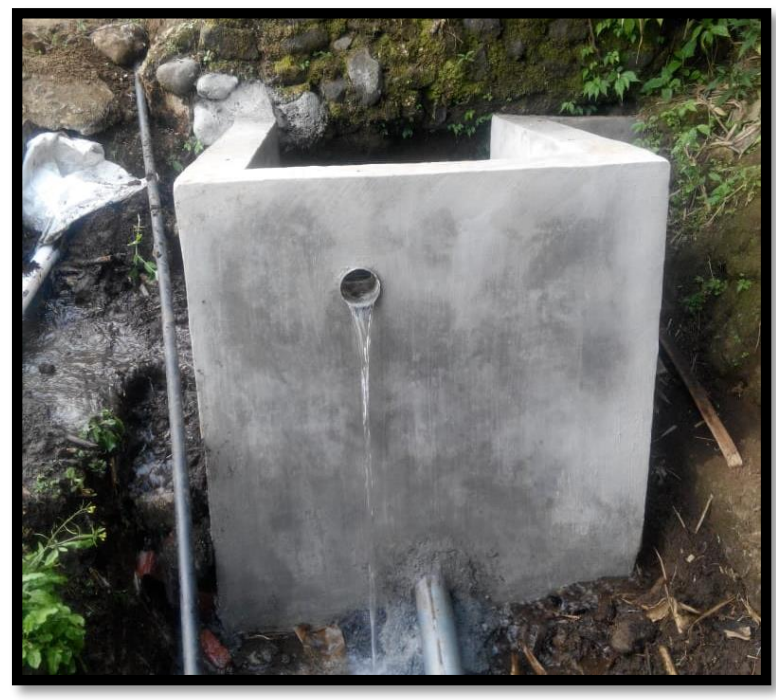

Gambar 3. Bak Tampung

Pada bak tampung ini terdapat dua saluran, saluran pertama menuju ke pompa hidram dan saluran kedua berada di bagian atas bak tampung. Saluran menuju pompa hidram berukuran 3 inchi, saluran di bagian atas bak tampung berfungsi untuk pembuangan air jika terjadi luapan volume air. Jika terjadi luapan volume air, maka air akan dialirkan menuju kolam dan bisa digunakan untuk irigasi.

\section{Instalasi pompa hidram dan pipanisasi}

Pompa hidram sudah terpasang dengan dudukan. Pipa dari bak tampung menuju pompa hidram berdiameter 3 inchi sepanjang $27 \mathrm{~m}$. Sedangkan pipa keluaran dari pompa hidram menuju tandon air berdiameter 1 inchi dengan jalur sepanjang $120 \mathrm{~m}$. Proses pemasangan instalasi pipa dan pompa hidram ini dilakukan bersama masyarakat sekaligus sebagai pelatihan instalasi dan perawatan kepada mitra secara langsung. Proses instalasi pipa ditunjukkan oleh gambar 4.
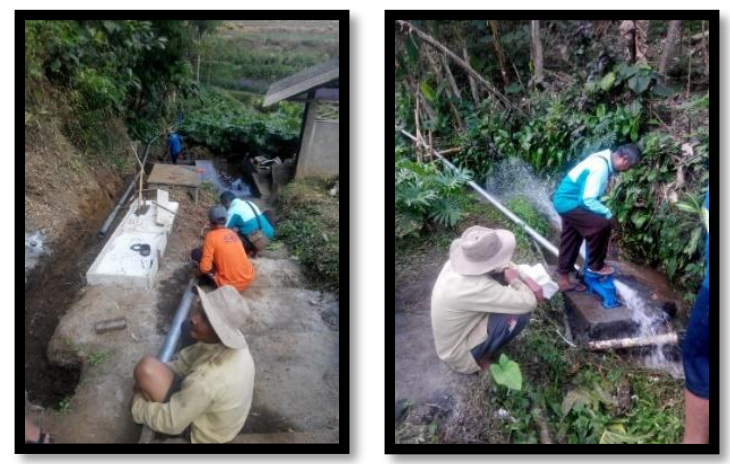

Gambar 4. Proses instalasi pipa dan pompa

Dalam pelaksanaan Program Kemitraan masyarakat ini terjadi beberapa kendala, diantaranya pompa yang lepas dari dudukannya dan debit keluaran air yang kurang optimum. Pompa hidram terlepas dari dudukannya, sehingga mengakibatkan pompa tidak berfungsi, hal ini dikarenakan tekanan air masuk kedalam pompa terlalu besar dan struktur rangka dudukan pompa kurang kuat. Struktur rangka dudukan ini kurang kuat dikarenakan tidak adanya perhitungan desain rangka dudukan pompa. Permasalahan rangka dudukan pompa ini terselesaikan dengan penghitungan ulang desain rangka dudukan pompa dan penginstalan kembali pompa hidram.

Permasalahan debit keluaran air yang kurang optimum, disebabkan oleh jalur pipa dari pompa hidram menuju tandon air yang tidak lurus, sehingga terjadi losses yang besar karena gesekan pada belokan jalur pipa. Perbaikan dilakukan dengan meluruskan mengoptimalkan jalur pipa sehingga keruguan (losses) karena gesekan bisa diminimumkan. Perbaikan jalur pipa ini mengahasilkan perubahan debit keluran air di tandon, yang awalnya 360 liter/jam menjadi 420 liter/jam.

\section{Pembuatan Sarana Pengomposan}

Pembuatan sarana pengomposan yaitu berupa komposter yang terbuat dari drum air. Dalam penggunaannya drum air ini dimodifikasi dengan dipasang keran dibagian bawah nya. Tujuan dari pemasangan kran air ini adalah untuk jalan pembuangan pupuk cair. Dibagian dalam drum, diberi saringan, untuk memisahkan kompos kering dan kompos basah. Pipa berlubang dipasang didalam komposter, dengan tujuan memberi supan oksigen pada saat proses pembusukan dari pupuk kompos.

\section{Proses pelatihan}

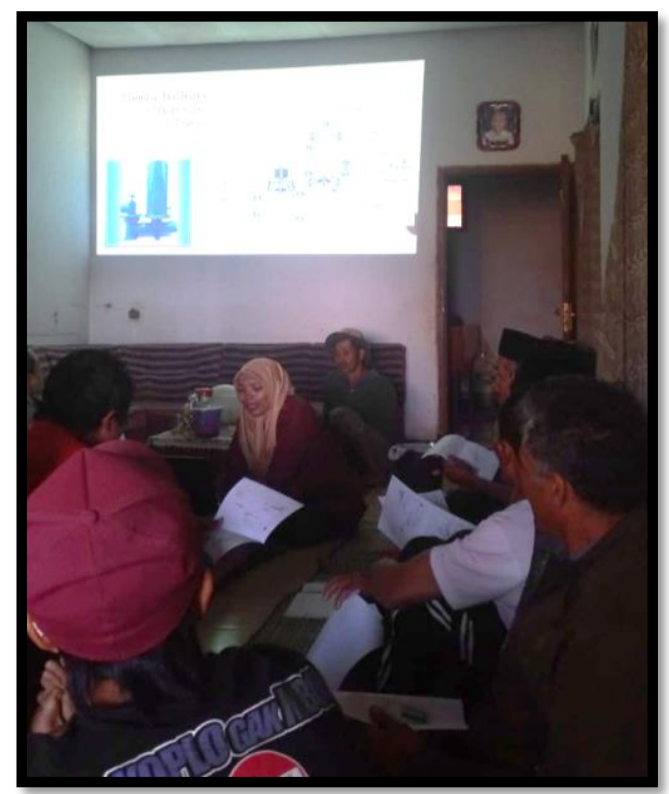

Gambar 5. Proses pelatihan poma hidram 
Proses pelatihan dibagi menjadi dua topic, topic yang pertama adalah pelatihan pompa hidram dan yang kedua adalah pelatian pembuaatan pupuk kompos.Topik pelatihan pertama adalah tentang teknologi yang digunakan berupa pompa hidram. Dalam pelatihan ini dijelaskan cara kerja pompa hidram serta cara perawatan terhadap pompa hidram. Pelatihan ini dilakukan karena berdasarkan pengalaman, di desa tersebut pernah menggunakan pompa hidram dan saat terjadi kerusakan di tahun 2004, pompa hidram tersebut tidak dapat diperbaiki.

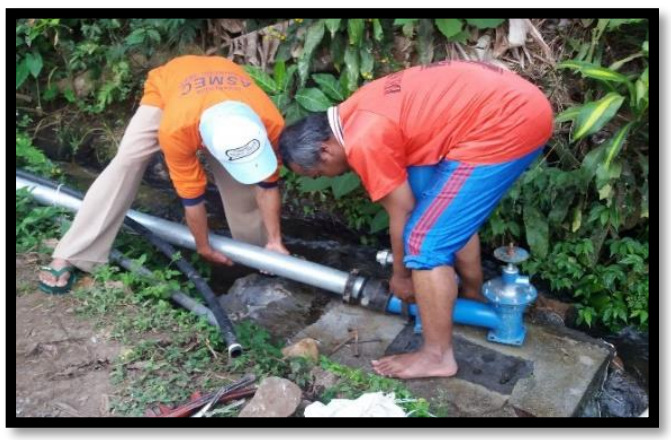

Gambar 6. Pelatihan instalasi pompa dan pipa.

Pompa hidram tidak dapat diperbaiki karena kesalahan metode perbaikan pompa serta minimnya pengetahuan warga tentang cara pengoperasian dan perawatan pompa hidram tersebut.Proses pelatihan ini seperti yang diperlihatkan pada gambar 5. Selain pelatihan secara teoritis, anggota kelompok tani juga melakukan praktek langsung dalam proses instalasi dan pengoperasian pompa hidram dengan tujuan kelompok tani ini akan lebih memahami dengan pelaksanaan praktik secara langsung, seperti yang ditunjukkan gambar 6 .

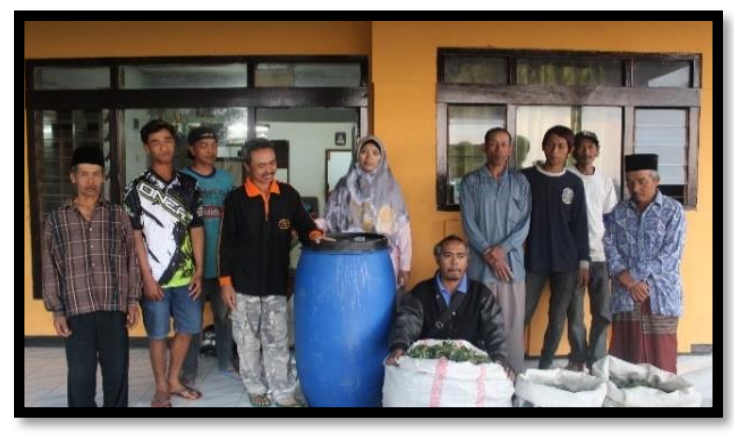

Gambar 7. Pelatihan pembuatan kompos

Topik lain dalam pelatihan ini adalah pelatihan pembuatan kompos dari limbah daunn mawar, seperti yang ditunjukkan gambar 7. Bahan yang digunakan dalam pembuatan pupuk kompos adalah limbah daun mawar, bakteri berupa EM4, gula sebagai sumber makanan dari bakteri dan air. Setelah smua bahan dicampur, bahan tersebut dimasukkan kedalam tong komposter. Proses pembuatan pupuk kompos ini memakan waktu sekitar 1 minggu

\section{Evaluasi keberhasilan program}

Pada tahap ini dilakukan proses evaluasi kepada kelompok tani mawar maju III. Proses evaluasi ini bertujuan untuk mengetahui tingkat keberhasilan dari program, baik berupa penguasaan masyarakat terhadap teknologi pompa hidram maupun kemampuan mereka untuk memanfaatkan limbah daun mawar menjadi pupuk kompos. Hasil dari evaluasi ini menunjukkan terjadi peningkatan pengetahuan dari masyarakat tentang pemanfaatan teknologi pompa hidram dan keterampilan mereka dalam membuat pupuk kompos.

\section{KESIMPULAN}

Hasil dari Program kemitraan masyarakat ini adalah:

a) Sarana Penyedia air bersih, berupa tandon air, bak tampung, instalasi pompa hidram dan pipanisasi.

b) Sarana pengomposan berupa drum komposter.

c) Peningkatan kualitas SDM (Sumber Daya Manusia) terutama peningkatan pengetahuan mereka tentang teknologi pompa hidram, teknik pengomposan. Selain meningkatnya engetahuan masyarkat, skill masyarakat dalam prktek pengoperasian pompa hidram serta pengolahan pupuk kandang juga meningkat.

\section{UCAPAN TERIMAKASIH}

Terimakasih kepada Kementrian Ristek DIKTI, yang telang mendanai kegiatan pengabdian masyarakat dalam bentuk Program Kemitraan Masyarakat.

\section{REFERENSI}

Çengel, Y. A., \& Cimbala, J. M. (2006). Fluid mechanics: Fundamentals and applications. Boston: McGraw-HillHigher Education.

Yovita. (2001). Membuat kompos secara kilat. Jakarta: Penebar Swadaya.. 